\title{
Motives and Motivation for Implementation of Public Private Partnerships (PPPs) in Housing Provision in Nigeria
}

\author{
Paschal Onyemaechi
}

PhD Candidate at Faculty of Business and Law, Leeds Beckett University, UK Paschaldozie2002@yahoo.com

Martin Samy

Professor of CSR and Effective Measurement, Faculty of Business and Law Leeds Beckett University, UK m.a.samy@leedsbeckett.ac.uk

\section{Doi:10.5901/mjss.2016.v7n2p149}

\section{Abstract}

\begin{abstract}
Purpose - The federal government of Nigeria in December 2011 formally adopted Public Private Partnership (PPP) as an alternative housing delivery option for Nigeria. However, evidence from available literature indicates there is the lack of empirical evidence on how the private and public sector can be better motivated to achieve improved results in PPP housing. The research therefore, investigated the Motives and Motivation for partnership between public and private sector in housing provision in Nigeria. The specific objectives are to identify and examine the motivating factors for the partnership of public and private sector operators in housing provision in Nigeria and examine how these factors can be enhanced to achieve better outcome for PPP housing in Nigeria. Methodology - A total of 24 housing PPP experts from both public and private sectors operators directly involved in the selected 8 case studies were selected and interviewed. Findings: The study indicates that derive to provide affordable housing, develop towns and cities, reduce acute housing shortage, eliminating of budget constraint, profit making and faster project completion are the motives and motivating factors for the government in PPP housing in Nigeria while the motivating factors for the private sector includes profit maximisation, large demand market, fast approvals. The study also indicated that to enhance these factors, there is need for a reform of the PPP housing policy to encourage and support private sector participation. Recommendation/Implication: The findings of the study implies that there is need to amend the PPP laws and policy with a view to encouraging and supporting the participation of the private sector in housing provision.
\end{abstract}

Keywords: Public private partnerships, Housing, Motives, Motivation, Nigeria.

\section{Introduction}

Housing is recognized world-wide as one of the basic necessities of life and a prerequisite to survival of man (Onibokun, 1990; UNCHS, 1996; Waziri and Roosli, 2013). It is an important component of human settlement and contributes to the quality of life, health, welfare as well as productivity of man (Ibem, 2010). The renowned economist Abraham Maslow ranks housing as basic need of man in his theory of hierarchy of needs (Erguden, 2001; UN-Habitat, 2006a). According a report by the United Nations Human Settlement Program (UNHSP, 2011), it is estimated that more than half of the world six billion people now live in cities, towns and other urban centres and current trend predicts that this will continue to increase. According to the report, over 90 percent urbanization has occurred in developing countries, with urban area receiving additional estimated 70 million new residents each year (UNHSP, 2011) This trend is especially prevalent in South Asia and sub-Saharan Africa, the two poorest regions in the world, where urban population is expected to double by the year 2030.(UNHSP, 2011). The desire for adequate and affordable housing also has strong link to the need for security, safety and poor socio-economic status of individuals and communities (Ibem, 2011) In spite of this widely acknowledged importance of housing and various efforts in making adequate and affordable housing available to majority of people, a large proportion of urban residents in less developed and developing countries do not have access to decent housing at affordable cost (Sengupta, 2006b; UN-Habitat, 2006a; Abdullahi, 2010; Ibem, 2011). As majority of urban residents in developing countries live in slums and poor housing condition (Rondinelli, 1990; UN-Habitat, 2006d; Ibem, 2011). Hence, inadequate housing has become a major challenge that has continued to receive attention from government and groups in many developing countries. For instance, investigation from previous studies reveal that successive administration in Nigeria had launched about eight public housing programme in the last few decades in the 
bid to address the increasing housing challenge in the country (Onibokun, 1985; Awotona, 1990; Akinmoladun and Oduwoye, 2007; Bala and Bustani, 2009) and these previous efforts and strategies could not achieve the desired objectives (Daramola, et al., 2005; Ibem, 2010).

Consequently, many governments around the world began to adopt a new approach where the government collaborates with the private sectors and acts as an enabler and facilitator of housing by providing the appropriate legislation, incentives and institutional framework for effective private sector partnership rather than direct government involvement (World Bank, 1993; UNCHS, 2000). One of the most common forms of the collaboration is public private partnerships - PPPs. PPPs have been defined by various studies (Xie and Stough, 2002; Mazouz et al., 2008; OECD, 2003; Ibem, 2010). In its simplest form, Fiszbein and Lowden (1999) defined PPPs as "the pooling of resources (financial, human, technical and intangibles such as information and political support) from public and private sources to achieve a commonly agreed goal" (Fiszbein and Lowden, 1999, p. 164). Whereas Kwak et al. (2009) views PPPs as a cooperative arrangement between the public and private sectors that involves the sharing of resources, risks, responsibilities and rewards with others for the achievement of joint objectives (Kwak et al., 2009, p.2). It has been also been defined as a collaborative effort among public, private and third sector organization based on mutual trust, division of labour and a comparative advantage in the sharing of responsibilities, risks and benefits (Ibem, 2010). PPP in housing therefore implies a framework where the government shares roles with the private and third sector (NGOs, CBOs, and Charities) in the effort to provide a decent and sustainable housing.

Several studies (Pomeroy et al., 1998; Sengupta, 2006b; Sengupta and Tipple, 2007; Abdul-Aziz, 2007; GloverThomas, 2007; PPIAF, 2007; Moskalyk, 2008; Ibem, 2009; 2010, 2012; Abdullahi and Aziz, 2011; Abdul-Aziz, 2012; Babatunde, 2012; Yuan et al., 2012) have been conducted on various aspect of the application of PPPs in housing delivery in countries such as UK, USA, Canada, Australia, China, Malaysia, Brazil, India, South Africa and Nigeria and many other developing countries. PPP in housing in Nigeria started in 2002 with the launch of the national housing Urban development policy (NHUDP) and was formally adopted in 2011 as a housing delivery policy through a policy stated issued by the federal Ministry of Lands, Housing and Urban development. However, since the introduction of PPP in housing provision in Nigeria, several studies (Mbamali and Okoli, 2002; Mayaki, 2003; Daramola et al., 2005; Ibem, 2009; 2012 Abdullahi and Aziz, 2011) has opined that PPP in housing is yet to make any significant impact in housing provision in Nigeria when compared with reports from other countries where PPP is succeeding. Hence the need to investigate and examine the motives and motivation for the adoption and operation of PPP in housing provision in Nigeria. This is certainly vital in providing factual judgment on the operation and assessment of the performance of PPPs in housing provision in Nigeria.

This study therefore undertook an in-depth investigation of the Motives and motivation for public private partnerships in housing in Nigeria. Hence the specific research objective are:

1. To identify and examine the motivating factors for partnership between public and private sector operators in housing provision in Nigeria.

2. To examine how these factors can be enhanced to achieve better outcome for PPP in housing in Nigeria.

While the research questions are:

1. What are the motivating factors for public private partnership in housing provision in Nigeria

2. How can the motivating factors of PPP in housing in Nigeria be enhanced for better outcome

According to the Cambridge English dictionary, motives means reason for doing something while motivation means the enthusiasm for doing something. In the context of this study, motives and motivation are used interchangeably to mean the propelling reasons for action.

\section{Literature Review}

This section traced the root of the housing problem in Nigeria, the various intervention by the government to addressing the housing challenge, the previous strategies engaged and these outcome of those strategies. It also reviewed the reason for those out. The section undertook and extensive review of literature on the application of PPP in housing in many countries. This is to establish trend, challenges, gaps, funding pattern, motivation for various partners and the findings of previous studies.

\section{Government's Intervention in Addressing the Housing Challenge in Nigeria}

In recognition of the housing problem and the need to provide decent and affordable housing for all Nigerians, the federal government of Nigeria has constantly intervened in the sector through various policies, programs and reforms earned at 
revolutionising the housing sector to achieve the objective of decent and affordable housing for the citizens. The first government intervention is housing problem in Nigeria was in 1928, during the bubonic plague of 1982 - 1929 (Agbola and Jinadu, 1997; Bala and Bustani, 2009; Ibem, 2010). This was followed by the establishment of several boards and agencies to facilitate government intervention in housing. This included the federal housing Authority - FHA, the Nigeria building standards - NBS, the federal mortgage bank - FMBN, the national housing Fund - NHF, presidential committee on housing etc (Bana, 1991; Ajalenkoko, 2001; Chukwujekwu, 2005; Bala and Bustani, 2009). In fact evidence shows that Nigeria has had six (6) major housing reforms and programmes since after independence in 1960, the housing shortfall has continued to rise unabated (Umeh, 2004; Nubi, 2008; Ibem, 2011).

Studies (Mba, 1992; Omole, 2001; UN-Habitat, 2006c; Ibem, 2010) concluded that past housing delivery strategies have failed to address the housing need of low-income people of Nigeria who constitute over $60 \%$ of the Nigeria Population and $80 \%$ of Nigeria's urban residents. Findings of some studies (Mustapha, 2002; Gana, 2002) offered an insight to the failure of these housing programs to include, poor funding, lack of proper organisation, inappropriate strategies, bureaucracy, politics and mismanagement of resources as well as the high cost of housing, the problems were articulated to by political, economic, organisation, environmental, and social problems. However, as noted by several Scholars (Awotona, 1990; Ogu and Ogbuozobe, 2001; Kabir, 2004) these intervention strategies and programs recorded modest achievement in providing subsidized housing for middle and high-income civil servant and individuals. Thus, from the foregoing, the previous government intervention strategies in addressing housing shortfall in Nigeria had followed an elitist orientation against the socio-economic context of the country where over $60 \%$ of the population and $80 \%$ of the urban population are low-income earners.

According to Waziri and Roosli (2013) the housing needs of Nigeria as at year 2000 was estimated at 8 million units for both rural and urban centres. To close this gap, previous studies advocated adequate involvement of the private sector to serve as the main vehicle for housing delivery (Ogunrayewa and Madaki, 1999; Yakubu, 2004; Aribigbola, 2008). The Un-Habitat (2006c) has stressed the need for a more market friendly approach and collaboration between the private and public sector to housing provision as none of the sectors can solve the problem alone. Hence public private partnership was adopted as the major vehicles for housing provision in Nigeria.

\subsection{PPP in Housing Delivery}

PPP in housing has been a source of debate among scholars on the appropriateness or otherwise of the strategy to housing development (Daramola et al., 2005; Glover-Thomas, 2007; Ibem, 2012; Abdul-Aziz, 2012; Suzanne and Dustin, 2012). Some scholars have argued that the model has been successful in some countries and if implemented with appropriate control mechanism the strategy is capable of revolutionizing the housing market and increasing housing supply (UN-Habitat, 2006a; Sengupta, 2006b; Sengupta and Tipple, 2007; Gbadeyan, 2011; Abdul-Aziz, 2012; Tserng, 2012;) while others have insisted that the application of PPPs model has failed to deliver the desired result in the housing sector (Daramola et al., 2005; Glover-Thomas, 2007; Ibem, 2010; Babatunde, 2012).

A study conducted by the United Nations Human Settlement Program in 2011 on PPPs and housing development reveals that a number of countries are embracing PPPs options as a way out of housing shortage. According to the report "in developing countries across Asia and Africa, PPPs are beginning to emerge as the prominent approach to urban housing policy, while some success has been documented in India" (UNHSP, 2011, p.31). It however stated that to the extent that housing PPP will flourish in poorer developing countries, their use is dependent among other things on the economic and political strength and housing policy and tradition of a particular nation (UNHSP, 2011). Therefore, application of this strategy to housing delivery has been drawn into question; hence, the study examines the motives for its application and the implications for housing delivery in Nigeria.

\subsection{PPP in Housing in Nigeria}

According to (Ibem, 2010) the involvement of private sector in public housing in Nigeria started in Lagos with the establishment of the New Towns development Authority (NTDA) in 1981. The NTDA was among other agencies charged with the responsibilities for supporting private-sector driven initiatives in housing delivery in Lagos state. This according to (Ibem, 2010) was re-enforced by the then new democratic government in Nigeria through the approval of the new National Housing Urban Development Policy (NHUDP) launched in 2002. According to Aribigbola (2008) the objective of the NHUDP was to ensure all Nigerians own or have access to decent, safe and sanitary housing accommodation at an affordable cost through private sector led initiatives. This kick started the first private sector involvement in solving the housing shortfall in Nigeria even though PPAIF (2007) reported that PPPs became popular in Nigeria in 2004 leading to 
the establishment of the regulatory agencies in 2005. Public-private partnership in housing is promoted in on the assumption that it encourages multi-sectorial participation, increases housing stock, increases affordability and accessibility and timely delivery of housing to citizens (Ikekpeazu, 2004; UN-HABITAT, 2006b; Shelter Afrique, 2008). Convinced by these apparent benefits, the government of Nigeria recently adopted PPP as a key policy in a bid to increase housing stock and affordability for all Nigeria. On December 2011, the Federal Government of Nigeria (FGN) through its Federal Ministry of Land, Housing and Urban Development (FMLHUD) made a policy statement that "the increasing deficit of decent and affordable housing in Nigeria's urban and rural areas pose major obstacles to economic growth and development to this end, the Ministry will collaborate with key actors and operators on housing sector through the establishment of viable partnership with private sector development and investors" (FMLHUD PPPs Guideline, 2011, p.1)

According to the policy guideline, the major objectives of the housing PPPs include:

1. To establish viable and sustainable partnership between the public and private sector in the delivery of affordable housing.

2. To foster partnership which leverages inputs from all stakeholders in the housing and urban development sector.

3. To facilitate provision of decent and affordable housing units in all towns and cities and rural areas with the view of reducing the acute shortage of housing in the country

4. To demonstrate viable approaches to the delivery of housing and ensure competitiveness and transparency in the process.

5. To promote the mobilization of bilateral and multilateral funding for housing and urban development.

6. To contribute to the operations of the Nigerian mortgage sector and encourage the emergence of a vibrant housing market.

7. To promote the development and operation of the housing co-operatives among others (FMLHUD, 2011).

The policy documents recognise stakeholders in Nigeria housing Public Private Partnership to include: the Federal Ministry of Lands, Housing and Urban Development, all states and all local government council, Real estate developers and investors, manufactures of building materials, financial institutions and fund providers, Universities, Polytechnics and Research institutions, Donor agencies, community based organisations, and NGOs, Relevant professional bodies and associations, housing co-operatives and constructions companies (FMLHUD, 2011). Even though the policy document recognise local government, CBOs and NGOs as stakeholders in Public Private Partnership housing in Nigeria, findings of previous studies (Daramola et al., 2005; Bala and Bustani, 2009; Ibem, 2011) concluded that in practice, CBOs and NGOs were not part of the housing PPP arrangement in Nigeria. From the above policy guideline, it can be concluded that PPP was adopted in housing provision in Nigeria to provide a viable and sustainable platform for providing decent and affordable housing units in all cities and towns in Nigeria with a view to reducing the acute housing shortage.

\section{Research Design/Methodology}

The data for analysis were sourced through face to face semi-structure in-depth interviews of purposely selected participants from both the public sector partner and private developers directly involved in all stages of the selected PPP housing projects. A total of 8 case studies of PPP housing projects were selected one from each of the six geopolitical zones of the country, one from the federal capital territory Abuja and one from a state that have adopted PPP as a housing delivery strategy.

From the government public sector partner side, a total of 16 person of minimum of deputy director and above were conveniently selected and interviewed. Out of the 16 public sector partners, 14 were representing federal housing agencies and Ministry while 2 represented state own housing agencies and Ministry. A total of 8 private developers who were directly involved in the selected 8 case studies were selected and interviewed, bringing a total of 24 participants. The respondents from the private developer were the most senior staff member directly involved on the PPP process and development of the selected project / case study.

An interview guide was prepared to ensure that same question were worded in predetermined fashion. The interview guide consisted of questions aimed that will enable the research answer the research question and achieve the objectives of the research. The interview were tape recorded with the permission and consent of the respondent and was transcribed from audio to readable text for ease of analysis.

To enhance the validity of findings, the researcher sourced secondary data from archival materials and review of literature. This enabled triangulation of data and contributed to the quality of data collected for the study. The data was analysed using content analysis with the help of Nvivos 10 software package. 


\section{Result/Study Findings}

The result from the interview reveals the following as motives for the public sector partners:

1) Solves the problem of budget constraints

2) Make profit from the sale of the housing units

3) Provision of decent and affordable housing to the citizenry

4) It reduces burden of housing provision from the government

5) Development town and cities

6) Faster project completion

7) Reduce the acute housing shortage

8) It is cheaper for the government since the funding comes from the developer

9) It creates room for influence by the officials as they determine who to partner with and on what terms.

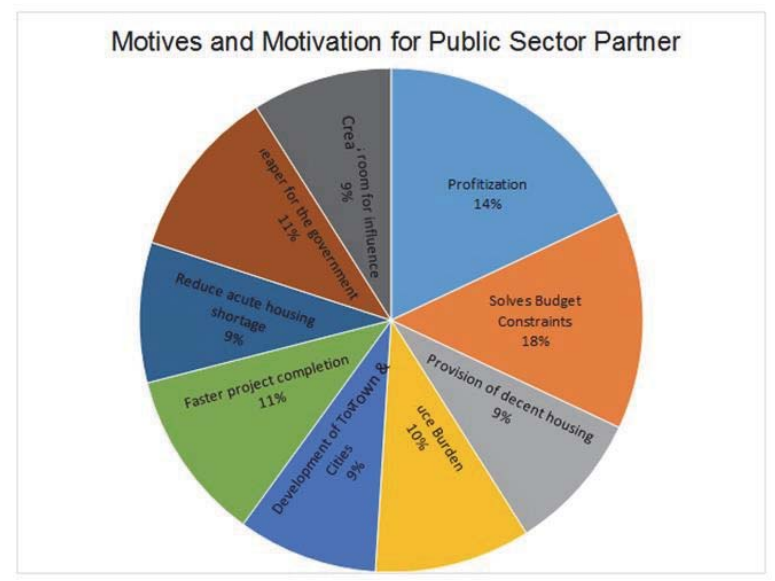

Figure 1 above shows motives and motivation of public sector partner in a PPP housing project.

Those interviewed identified the motives and motivation for the private sector partners to include:

1. Profit maximisation

2. Large market.

3. Availability of land for the project.

4. Marketability of the housing units. Based on the fact that it is a government project, people have confidence on the tittle documents and originality of the offer and tends to buys them off very fast.

5. Project Viability and quick return on investment. The housing are sold out as soon as construction starts and even before the completion thereby providing cheap funds for financing the project itself.

6. Location of the project. Project located in choice areas are very competitive

7. Price of housing units. The prices are market based and the developer participate in setting the price.

8. The Profit margin are competitive

9. Fast approvals for building and less interference from the government housing regulatory bodies. 


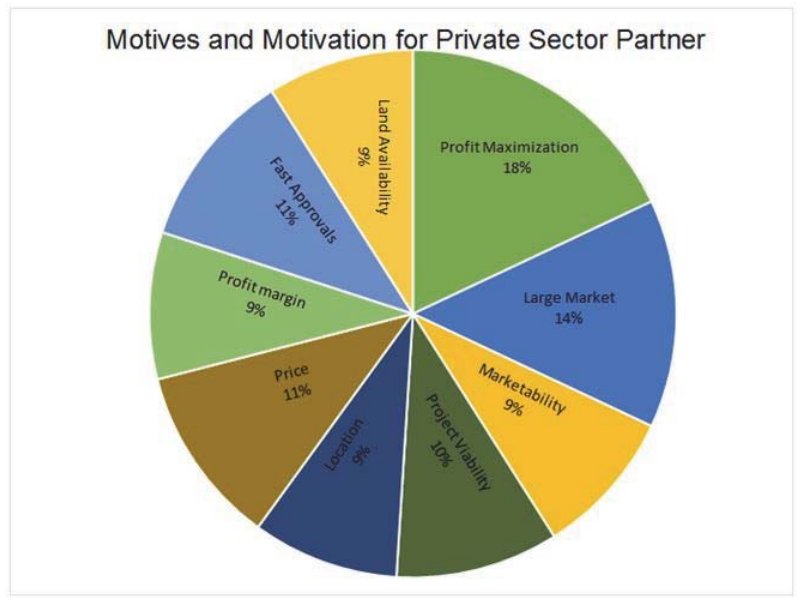

Figure 2 above shows motives and motivation of private sector partner in a PPP housing project.

\section{Discussion of Findings}

From the Findings above, it is obvious that one of the common motives and motivation for PPP housing in Nigeria for both the public sector partner and the private sector partner is profitability and personal gains. This adds up to the cost and leads to high cost of housing units procured through PPP. This explains the findings of previous studies (Ibem 2010; Onyemaechi et al., 2015) which identified inability of the current PPP model to address the issues of affordability as one of the major reasons why the strategy has not yielded the desired result in Nigeria (See also Daramola et al., 2005; Abdullahi, 2010). Also, according to the findings of Yuan et al., (2010) on PPP housing in China, the study recorded that the motives of government of China in adopting PPP in housing was driven by the huge housing need triggered by the Global crises of 2008 and the need to provide more houses for the low income. This aligns with the findings of this study that one if the motives of the Nigeria government is to address the acute housing shortage in the country. Another very critical finding the study is that that there is large demand side for housing and slower supply side which guarantees quicker sales and fasters return on investment. This derives the private operators to invest their money with some level of market demand surplus guarantee. This agrees Sengupta (2006b) which recorded that PPP made faster impact and produced better outcome in Tamil-Nadu that Kolkata even through it was first lunched in India in Kolkata due to the strategy and motivations of the private partners and the buy-in of the locals. Also, this explains the findings of Ibem, 2009 which noted that partnership with private developers will lead to faster completion of housing project and will improve the housing quality. It is obvious that the operating motives defers from the intended motives as shown on the PPP guideline issued by the FMLHUD discussed on the literature review section of this study. The respondents attributed this to poor implementation and enforcement of the policies and guideline. This perhaps explains the call and findings of Abdul-Aziz, 2012 that countries like Nigeria, South Africa, and Bulgaria which shares similar PPP housing format and market with Malaysia should examine the control mechanism adopted by the public agencies involved in PPP housing in their countries.

Furthermore, the respondents suggested that to enhance the motivating factors for public private partnerships in housing provision in Nigeria, there is need to overhaul the PPP housing laws to incorporate the key motivators of the partners. The finding is in line with the findings of previous studies (Gana, 2002; Abdullahi, 2010; Leland and Read, 2012; Ibem, 2012) which suggest that the government needed to do more in terms of providing incentives as a way to encourage and sustain private sector participation in housing provision. Also, Abdul-Aziz 2012 recorded that government encouragement and commitment to the private developers contributed to the success of PPP in housing in Malaysia.

\section{Conclusion and Recommendation}

The findings of the study has clearly indicated that the motives and motivation of the public sector partner in PPP housing is to reduce acute housing shortage by providing decent housing for its citizens leveraging on the funding and expertise 
of the developer and to make profit from the housing units provided. While the motives and motivation for the private developer is to leverage on the good name of the government, have access to buildable land, secure quick approvals, avoid strict supervision and maximize profit for their company. The result of these is that the housing units are produced at higher cost that are not affordable to the low income and PPP is unable to address the housing needs of the people because the low income who constitute the majority of those in need of housing cannot afford the housing units procured through PPP. The implication of the findings of this study implies that there is need for overhauling of the PPP housing laws and policies in Nigeria with the view to including laws and policies that will encourage the private sector participation and eliminate public sector profiteering and corruption. Secondly, these motivating factors has strong link with the success and improved outcome of PPP in housing in Nigeria. Thirdly, this study has bridged the gap and improved the understanding of the factors motivating the operators and partners in PPP housing in Nigeria and how these factors can be enhanced.

The study recommends practical steps that will address the policy gap, encourage greater participation of the private sector in housing provision, eliminate public sector corruption and improved the outcome of PPP in housing.

1) Remove profit as a reward for government in a PPP housing project and convert its portion of profit reward to subsidy for low-income earners

2) Come up with strict monitoring and control mechanism to ensure compliance to the original objectives and motives of the policy

3) Reduce the profit margin on PPP housing for private developers

4) Ensure Transparency and competitiveness in the bidding process. This will eliminate corruption and overbearing influence of government official in the housing agencies

5) The government can consider incentives for private developers. Some of such incentives incudes: Tax waivers for PPP low-cost housing related materials, Assurance from government to buy off on completion, all housing units produced in a PPP projects, Provision of cheap and long term funding facilities and reward for innovations brought by developer leading lower cost of production within the approved standard, and Free land as contribution of the government without any payback price.

This study therefore conclude that reforming the PPP housing laws by the government with the aim of enhancing these motivators for PPP housing will encourage greater participation of the private sector in housing provision and ultimately lead to better outcome of PPP in Nigeria.

\section{References}

Abdul-Aziz, A. R. (2007) Successful delivery of Public-Private Partnerships for Infrastructure Development. Journal of Construction Engineering and Management, vol. 133(12), pp. 918-931.

Abdullahi, B. and Aziz, W (2011) Pragmatic housing policy in the Quest for low-income group housing delivery in Malaysia. Journal of Design and Built environment. vol. 8, pp. 21-38.

Abdullahi, B. (2010) Nigeria Housing policy and Public Private Partnership (PPP) strategy: Reflection in achieving home ownership for low income group in Abuja-Nigeria. Urban Dynamics and Housing Change. Paper presented at the 22nd international Housing Research conference in Istanbul 4-7 July.

Abdul-Aziz, A. R. (2012) Control Mechanism exercised in Malaysia housing Public Private Partnership: Construction Management and Economics, vol. 30, issue1, pp. 37-55.

Agbola T. and Jinadu A. M. (1997) Forced eviction and forced relocation in Nigeria: The experiences of those evicted from Maroko in 1990. Environment and Urbanisation, vol. 9(2), pp. 271-288.

Ajalenkoko, K. S. (2001) Sustainable housing development in Nigeria. The Financial and Infrastructural implication. Paper presented at the International conference on spatial information for sustainable development in Nairobi. Kenya 2-5 October. [Online]. [Accessed 12 March 2014]. Available at: <http//cepnigeria.com>.

Akinmoladun, O. and Oluwoye, J. (2007) An Assessment of why the problem of housing shortages persists in developing countries: A case study of Lagos Metropolis Nigeria. Pakistan Journal of social science, vol. 4, no. 4, pp. 587 - 598.

Aribigbola, A. (2008) Housing policy formulation in developing countries: evidences of program implementation from Akure, Ondo State Nigeria. Journal of human Ecology, vol. 23, pp. 125-134.

Awotona, A. (1990) Nigeria Government participation in housing: 1970-1990 Habitat International, vol. 14(10), pp. 17-40.

Babatunde, S. (2012) Critical Success Factors in PPP on infrastructure development in Nigeria. Journal of facilities management, vol. 10 ISS.3, pp. $212-225$.

Bala, K. and Bustani, S. A. (2009) A review of housing delivery efforts in Nigeria. Paper presented at the ISA international Housing Conference, Housing Assets, Housing People. Department of Urban Studies University of Glassgow, September 1st - 4th. [Online]. Available at: <www.gla.ac.uk/media/media_12967_en.pdf>.

Bana, P. (1991) Housing the urban poor in Nigeria: The Nigeria institute of Architects Journal 6(1), pp. 22-25.

Chukwujekwu, I. E. (2005) The role of housing corporation in housing delivery. A cases study of Kogi Investment and properties Ltd. 
Housing Today the journal of Association of housing corporations of Nigeria (AHCN), vol. 1(9), pp. 6-9.

Daramola, A. S., Alagbe O., Aduwo, B. and Ogbiye, S. (2005) Public-Private Partnerships and housing delivery in Nigeria. Publication of Reports, School of architecture, Covenant University, Cannanland Otta, Nigeria, vol. 1, January 1.

Erguden, S. (2001) Low-cost housing Policies and constraints in developing Countries: Paper presented at the international conference on spatial information for sustainable development, Nairobi Oct, 10. [Online]. [Accessed 4 March 2015]. Available at: $<$ www.unchs.org $>$.

Federal Ministry of Lands Housing and Urban Development (FMLHUD) (2011). Public- Private Partnership Guidelines for investment in Housing Development. Federal Republic of Nigeria.

Fiszbein, A. Lowden, P. (1999) Working together for a change: Government, civic and business partnership for poverty reduction in Latin American and the Caribbean. A publication of the Department for International Development (DFID) Washington DC.

Gana, M. (2002) Towards effective private sector participation in housing development in Nigeria. The FCT experiment Housing today, The Journal of the association of Housing Corporation of Nigeria, vol. 16. pp. 6-10.

Gbadeyan, R. (2011) Private sector's contribution to the development of the Nigeria Housing Market. Journal of social science, vol. 3(2), pp. 104-113.

Glover -Thomas, N. (2007) Joint working; Reality or Rhetoric in housing the mentally vulnerable. Journal of social welfare and family law. vol. 39 no.3-4, pp. 217-231.

Ibem, E. O. (2012) Public Private Partnership in urban housing delivery in Nigeria: Evidence from Ogun State International Journal of Architecture and urban development, vol. 2, no. 2.

Ibem, E. O. (2011a) Evaluation of Public Housing in Ogun State, Nigeria. Unpublished PhD Thesis, School of Post Graduate Studies, Covenant University, Otta, Nigeria.

Ibem, E. O. (2011b) Public Private Partnership in Housing in Lagos megacity Region Nigeria: International Journal of Housing Policy (IJHP), vol. 11 (2), pp. 133-154.

Ibem, E. O. (2010) An assessment of role of government in public private partnership in housing delivery in Nigeria. Journal of construction in Developing Countries, vol. 15(5), pp. 23-48.

Ibem, E. O. (2009) Community-led infrastructure provision in low-income urban communities in developing counties. A case study of Ohafia Nigeria. Elsevier vol. 26(3), pp. 125-132.

Ikekpeazu, F. (2004) New trends in low-cost housing delivery system in Nigeria: An overview of the Public-Private Partnership approach. Housing Today - The Journal of the association of Housing Corporation of Nigeria, vol. 1(8) pp. 30-36.

Kabir, O. K. (2004) Low cost Technology and mass housing system in Nigeria housing. Journal of Applied Sciences. vol. 4(4), pp. 565567.

Kwak, Y. H., Chih, Y. and Ibbs, C. W. (2009) Towards a comprehensive understanding of Public Private Partnership for infrastructure development. California Management Review, vol. 5, no, 2.

Leland, S. and Read, D. (2012) Stimulating Real estate development through Public Private Partnerships: Assessing the perceived opportunity and challenges. Public administration Quarterly, University of North Carolina, Charlotte, vol. 36(3), pp. 311-340.

Mba, H. C. (1992) The dilemmas of housing programmes in Nigeria In Mba, H.C., Ogbazi, J. U. and Efobi, K. O. (1992) (eds). Principles and Practice of urban and regional planning in Nigeria. Awka. Mekslink Publishers Nigeria, pp. 52-62.

Mbamali, I. and Okoli, O. (2002) Affordable housing for low income group in Nigeria. A redefinition of the basic parameters. Housing Today. A Journal of the associate of housing cooperation of Nigeria, vol. 1(5), pp. 15-21.

Mayaki, S. S. (2003) Private Sector Treatment in mass housing the way formed housing today. Journal of the association of Housing Corporation of Nigeria, vol. 1(7), pp. 31-34.

Mazouz, B., Facal, J. and Viola, J. (2008) Public-Private Partnerships. Elements for a project-based management typology. Project Management Journal, vol. 39(2), pp. 98-110.

Moskalyk, A (2008) The role of PPP in funding social Housing in Canada. Canadian Policy and Research Network Inc. and Social Housing Services Corporation. University of Western Ontario

Mustapha, A. (2002) Overview of housing and urban development program since independence. A Journal of Association of Housing cooperation of Nigeria, vol. 1 (6), pp. 28-30.

Nubi, O.T. (2008) Affordable Housing Delivery in Nigeria. The south African Foundation International Conference and Exhibition, Cape Town, Oct. pp. 1-18.

Ogbazi, J. (1992) Historical development of urban planning in Nigeria. In Mba, H.C. Ogbazi, J. U. and Efobi, K. O. (Eds) principles and practice of urban and regional planning in Nigeria (pp. 12 - 19) Awka: Mekslink Publishers Nigeria.

Ogu, U. and Ogbuozobe J. (2001) Housing policy in Nigeria: Towards enablement of private housing development. Habitat International, vol. 25(4), pp. 473-492.

Ogunrayewa, M.A and Madaki, S.A. (1999) The new Housing policy and shelter challenge. Journal of Environmental Sciences, vol. 3(1) pp. 74-79.

Omole, F. K. (2001) Basic issues in Housing Development. Ondo: Femobless Publishers.

Onibokun, A. G. (1990) A Review of government housing policy in Nigeria 1979-1983 a critical review in urban housing in Nigeria. Ibadan: Nigeria Institute for Social \& Economic, Research (NISER).

Onibokun, R. (1985) Housing in Nigeria Ibadan: Nigeria Institute for Social \& Economic, Research (NISER) Ibadan.

Onyemaechi, P., Samy, M. and Pollard, D. (2015) An examination of the Critical Success Factors for Public Private Partnership in Housing Projects in Nigeria. Journal of sustainable development in Africa, vol.17 no,3 
Okupe, O (2002) Problem of Real Estate Developers in Nigeria. Paper presented a workshop organized by the Nigeria Institute of Quantity Surveyor, Abuja.

Pomeroy, S., Wallace, J., Sheehan, R. (1998) The role of Public Private Partnership in producing Affordable Housing: Assessment of the U.S Experience and lessons for Canada. Canada Mortgage and Housing Corporation (CMHC).

Public Private Infrastructure Advisory Facility (PPIAF) (2007). Public-Private infrastructure units. Lesson for their design and use in infrastructure, would Bank Washington D.C.

Rondinelli, D. A. (1990) Housing the urban poor in developing countries. Other policy options for National Shelter Strategies are examined since 25 conventional one are inadequate. America Journal of Economics and sociology, vol. 49(3), pp. 257-269.

Sengupta, U. and Tripple, G. (2007) The performance of public sector housing in kalkata India in post reform milieu. Urban studies, vol. 44 (10), pp. 2009-2027.

Sengupta, U. (2006b) Government intervention and public private partnerships in Housing delivery Kolkata. Habitat International, vol. 30(3), pp. 448-461.

Shelter Afrique (2008) Mortgage Financing for increased access to housing in Africa: Symposium organized jointly and Shelter Afrique and the Ministry of Housing Republic of Togo. Held in Lome, 10 June, 2008. [Online]. [Assessed 22 July 2013]. Available at: $<$ http://www.shelterafrique.org>.

Tserng, H.P., Russell, J.S., Ching-wen, H. and Chi, I. (2012) Analyzing the Role of Public private Partnership units in promoting PPPs using new institutional economics and a case study. Journal of construction engineering and management, vol. 138, ISS 2, pp. 242-249.

Umeh, L.C. (2004) Towards improving degraded urban neighbourhoods in Nigeria. Prospects for residential participation in Mba, H.C., Uchegbu, S.N., Udeh, C.A. and Moughalu, L.N. (ED) Management of environmental problems and Hazards in Nigeria. Hants, Ashgate Publishing LTD, pp. 285-297.

UN-Habitat (2006a) Shelter for all: The potential of housing policy in the implementation of the Habitat agenda, Nairobi. [Online]. [Accessed 27 Feb. 2014]. Available at: <http/www.unhabitta.org>.

UN-HABITA (2006c) National Trend in Housing - production practices, volume 4: Nigeria. UN-Habitat information services [Online]. [Accessed 10 March 2013]. Available at: <http//www.Unhabitat.org>.

UN-HABITAT (2006d) National experiences with shelter delivery for the poorest groups. Nairobi: United Nation Habitat information service [Online]. [Accessed 10 March 2013]. Available at: <www.unhabitat.org>.

United Nations Center for Human Settlements (UNCHS) (1996). An Urbanizing world: Global reports on human settlement: Oxford: Oxford University Press.

United Nations Human Settlement Programme (UNHSP) (2011) Public Private Partnership in Housing and Urban Development: The Global urban Economic dialogue series. Series 978-92-1-132027-5, Volume 978-92-1-132356-6, no. HS/062/11E. [Online]. [Accessed 10 March 2014]. Available at <www.unhabita.org/publications>.

Waziri A. G. and Roosli. R. (2013) Housing policies and Programmes in Nigeria: A review of concept and implementation. Business Management Dynamics, vol. 3, no. 2.

Xie, Q. and Stough, R. (2002) Public Private Partnerships in Urban Economics development and prospects of their applications in China. Paper for the international Conference on Transitions in public Administration and Governance in Beijing. June 15-19. [Online]. [Accessed 18 August 2013]. Available at: <http://upanl.un.org/intradoc/groups/public/documents/ASPA/UNPAN0044644.pdf.

Yakubu, T. (2004) Federal Mortgage Bank of Nigeria in perspective. In: Homes and property guide B Gold Communication, Isolo, Lagos, vol. 1, no. 2, pp. 36-69.

Yuan, J., Guang, M., Wang, X., Li, Q. and Sikbniewski, M. (2012) Quantitative SWOT analysis of Public Housing Delivery by Public Private Partnerships in China based on the perspective of the public sector. Journal of Management of Engineering, vol. 28, no 4, pp. 407-420. 